\title{
Characteristics of dew events in an arid artificial oasis cropland and a sub-humid cropland in China
}

\author{
MENG Yao, WEN Xuefa* \\ Key Laboratory of Ecosystem Network Observation and Modeling, Institute of Geographic Sciences and Natural Resources \\ Research, Chinese Academy of Sciences, Beijing 100101, China
}

\begin{abstract}
Dew is an important source of water which significantly influences the physiological status of vegetation and the microclimate environment. For quantifying the characteristics of dew events and analyzing the underlying mechanism of dew formation in different ecosystems, we measured, based on the flux-profile method, the amount, frequency and duration of dew events in two croplands, an arid artificial oasis cropland in Zhangye, Gansu province and a sub-humid cropland in Luancheng, Hebei province in China. The results showed that dew events were observed in a total of 69 days in Zhangye, which accounted for $59 \%$ of the growing season (from 28 May to 21 September, 2012), while 128 days in Luancheng, which accounted for $79 \%$ of the growing season (from 5 April to 13 September, 2008). The frequencies of dew events were 2.8 and 2.4 times of those of precipitation in Zhangye and Luancheng, respectively. In addition, the dew amount reached up to 9.9 and $20.2 \mathrm{~mm}$ in Zhangye and Luancheng, which accounted for $9.5 \%$ and $4.1 \%$ of precipitation, respectively. The average amount of dew was 0.14 and $0.16 \mathrm{~mm} / \mathrm{night}$ in Zhangye and Luancheng, respectively and the duration of dew events ranged from 0.5 to $12.0 \mathrm{~h}$ in the two study sites. Dew amounts were associated with the gradient of atmospheric water vapor concentration and dew duration $(P<0.001)$ in both the two sites. The result implies that dew events play a more important role in crop growth in arid areas in comparison to sub-humid areas considering the dew occurrence frequency and the amount per night.
\end{abstract}

Keywords: dew amount; frequency of dew; duration of dew; flux-profile

Citation: MENG Yao, WEN Xuefa. 2016. Characteristics of dew events in an arid artificial oasis cropland and a sub-humid cropland in China. Journal of Arid Land, 8(3): 399-408. doi: 10.1007/s40333-016-0006-y

Dew formation is a widespread meteorological, hydrological and ecological phenomenon that occurs in both arid and humid areas. Moreover, dew is an important source of water that may significantly influence the physiological status of vegetation and microclimate environment $(\mathrm{Xu}$ et al., 2013; Uclés et al., 2014). Although the amount of dew is very small, it is extremely important in arid areas and during dry period in humid areas (Agam and Berliner, 2006). Nevertheless, dew can relieve water stress in some cropland ecosystems (Beysens et al., 2005).

Dew plays a more important role as a hydrological input in arid areas than in humid areas (Beysens et al., 2007; Sharan et al., 2007). For example, in the Taklimakan Desert, the amount of dew accounted for $66.7 \%$ of the total precipitation $(19.3 \mathrm{~mm}$ ) in summer (Hao et al., 2012). The amount of dew was found to contribute $94 \%$ of the total precipitation $(0.8 \mathrm{~mm})$ during the dry period in the Mediterranean (Uclés et al., 2014). In comparison, in a humid area such as Wageningen in Netherlands, the average annual amount of dew only accounted for approximately

${ }^{*}$ Corresponding author: WEN Xuefa (E-mail: wenxf@igsnrr.ac.cn)

Received 2015-06-28; revised 2015-12-28; accepted 2016-01-05

(C) Xinjiang Institute of Ecology and Geography, Chinese Academy of Sciences, Science Press and Springer-Verlag Berlin Heidelberg 2016 
$4.5 \%$ of the annual precipitation (more than $800 \mathrm{~mm}$ ) (De Roode et al., 2010). Similarly, in a semi-humid area such as the Sanjiang Plain in China, the average amount of dew only accounted for $4.9 \%$ of the annual precipitation $(410 \mathrm{~mm}$ ) (Yan and Deng, 2004).

Because of the increasing atmospheric humidity, the frequency of dew is likely to increase in the future (Dai, 2006; Willett et al., 2007). It is more important to measure the frequency and duration of dew events than the dew amount (Dietz et al., 2007; Kabela et al., 2009). For example, the frequency and duration of dew in Wageningen, Netherlands were $70 \%$ and $16.4 \mathrm{~h} / \mathrm{night}$, respectively, even though the amount of dew was quite small compared to the volume of precipitation (De Roode et al., 2010). The frequency and duration of dew events in the Negev Desert, an arid area, were 55\% and $7.6 \mathrm{~h} /$ night, respectively (Zangvil, 1996); and in a semi-arid area such as Almería in Spain, the frequency and duration were $50 \%$ and $6.5 \mathrm{~h} / \mathrm{night}$, respectively (Moro et al., 2007).

Dew events can change the micrometeorological environment for crop growth. The presence of dew on leaves can increase the local humidity and reduce transpiration rate (Barradas and Glez-Medellín, 1999). It promotes photosynthesis and delays the wilting of leaves (Cosh et al., 2009), promotes the absorption of nutrients (Xu et al., 2013) and increases aboveground growth of plants (Zhuang and Ratcliffe, 2012). Dew can also alter the predawn water potential of leaves (Kim and Lee, 2011) and the isotopic composition of leaf water (Wen et al., 2012). The condensation and evaporation of dew can change the distribution of latent and sensible heat transfer from leaves and reduce the possibility of freezing injury to crops (Madeira et al., 2001). However, dew-covered plant leaves are more vulnerable to diseases than those under dry condition (Wilson et al., 1999; Agam and Berliner, 2006).

In all, dew is an important supplement water source in arid and semi-arid areas (Xu et al., 2013), and the frequency of dew events is likely to increase and exert different impacts in different climate areas in the future under the worldwide increasing trend of atmospheric humidity (Dai, 2006; Willett et al., 2007). In this research, two croplands were selected in different climate areas for the purpose of comparison. One cropland is in Zhangye, Gansu province, which is an arid artificial oasis zone. The other was in Luancheng, Hebei province, which is a sub-humid area. In this study, a comprehensive comparison was made between these two sites to analyze the amount, frequency and duration of dew events, as well as the underlying mechanism of dew formation and to illustrate the differences in the characteristics of dew events. The results may provide scientific data for better understanding the importance of dew in arid and sub-humid croplands in China.

\section{Materials and methods}

\subsection{Study area}

The experiment was carried out in an arid artificial oasis cropland in Zhangye, Gansu province, and a sub-humid cropland in Luancheng, Hebei province, China.

The study in Zhangye $\left(100^{\circ} 22^{\prime} \mathrm{E}, 38^{\circ} 51^{\prime} \mathrm{N} ; 1,550 \mathrm{~m}\right.$ asl $)$ is part of the Heihe Watershed Allied Telemetry Experimental Research (HiWATER) program (Li et al., 2013). During the past 50 years, the annual average temperature was $7.4^{\circ} \mathrm{C}$ and annual precipitation was $128.7 \mathrm{~mm}$. The local cropping system is single crop per year, and the crop is spring maize. The main water source for the crops is irrigation. During the study year 2012, the cropland in Zhangye was flood irrigated four times: 6 June, 2 July, 28 July and 25 August. Film mulching was used to conserve soil water and the coverage rate was $60 \%$. Spring maize was planted on 20 April and harvested on 22 September 2012. The maximum leaf area index (LAI) was $5.6 \mathrm{~m}^{2} / \mathrm{m}^{2}$ and the canopy average height was $2.1 \mathrm{~m}$. The experiment was conducted between 28 May and 21 September 2012. More details of the study site can be found from Huang and Wen (2014) and Yang et al. (2015).

The other study site located in Luancheng $\left(114^{\circ} 40^{\prime} \mathrm{E}, 37^{\circ} 49^{\prime} \mathrm{N} ; 50 \mathrm{~m}\right.$ asl $)$ is part of the Chinese Ecosystem Research Networks (CERN) of the Chinese Academy of Sciences. During the past 50 years, the annual average temperature was $13.5^{\circ} \mathrm{C}$ and mean annual precipitation was $520.7 \mathrm{~mm}$. The crops for the double-cropping system were winter wheat and summer maize. In this study, 
winter wheat was sown from 23 to 25 October 2007 and harvested from 16 to 19 June 2008 . Summer maize was planted inside the mature wheat crop from 9 to 13 June and harvested on 2 October 2008. The cropland was flood irrigated twice: the beginning of April and the middle of July. The maximum LAI of winter wheat was $4.2 \mathrm{~m}^{2} / \mathrm{m}^{2}$ and the canopy average height was 0.75 $\mathrm{m}$, and they were $4.5 \mathrm{~m}^{2} / \mathrm{m}^{2}$ and $2.7 \mathrm{~m}$ for summer maize, respectively. The observation was conducted between 5 April and 13 September 2008. More details about the study site could be referred from Wen et al. (2012) and Xiao et al. (2012).

\subsection{Water vapor flux and micrometeorological observation}

In this study, the flux-profile method was used to measure the water vapor flux in Zhangye (Huang and Wen, 2014), which was based on the data taken from wavelength-scanned cavity ring-down spectroscopy (Model L1102-i, Picarro Inc., USA) and tunable diode laser absorption spectroscopy (Model TGA100A, Campbell Scientific Inc., USA) in Luancheng (Wen et al., 2012). In the experiment, the two intakes were set to 0.5 and $1.5 \mathrm{~m}$ above the canopy and adjusted following the canopy growth. In Zhangye, the heights of the two intakes increased from 0.6 and $1.6 \mathrm{~m}$ at the beginning to 2.55 and $3.55 \mathrm{~m}$ at the end of growing season. In Luancheng, the heights of the two intakes increased from 0.6 and $1.6 \mathrm{~m}$ at the beginning to 1.1 and $2.1 \mathrm{~m}$ at the end of the growing season for winter wheat, and increased from 1.1 and $2.1 \mathrm{~m}$ at the beginning to 3.2 and $4.2 \mathrm{~m}$ at the end of the growing season for summer maize. The flux footprint in the measurement is affected by the property of the upwind source area, which can be weighted by the footprint function (Zhang and Wen, 2015). In the study sites, the effective fetch is over $200 \mathrm{~m}$, which is enough for the measurement.

The eddy covariance system consists of a 3-axis ultrasonic anemometer (Model CSAT-3, Campbell Scientific Inc., USA), a $\mathrm{CO}_{2}$ and $\mathrm{H}_{2} \mathrm{O}$ concentration analyzer (Model LI-7500, Licor Inc., USA) and a data acquisition system (Model CR5000, Campbell Scientific Inc., USA). The system was installed at $4.5 \mathrm{~m}$ height above surface ground in Zhangye and $3.5 \mathrm{~m}$ in Luancheng. The auxiliary micrometeorological observation data include net radiation, air temperature, relative humidity, wind direction, wind speed, atmospheric pressure and precipitation.

\subsection{Calculation of net ecosystem $\mathrm{H}_{2} \mathrm{O}$ flux}

We established the flux-profile method based on the Monin-Obukhov (MO) similarity theory (Businger et al., 1971). The net ecosystem $\mathrm{H}_{2} \mathrm{O}$ flux $\left(F_{E T}, \mathrm{~g} \mathrm{H}_{2} \mathrm{O} /\left(\mathrm{m}^{2} \cdot \mathrm{s}\right)\right)$ between vegetation and atmosphere is defined as:

$$
F_{E T}=\rho K_{q} \frac{q_{1}-q_{2}}{z_{2}-z_{1}} .
$$

Where $\rho$ is the air density $\left(\mathrm{g} / \mathrm{m}^{3}\right) ; K_{q}$ is the eddy diffusivity $\left(\mathrm{m}^{2} / \mathrm{s}\right) ; z_{2}$ and $z_{1}$ are the upper and lower intake heights (m), respectively; and $q_{2}$ and $q_{1}$ are the specific humidity $(\mathrm{g} / \mathrm{g})$ at $z_{2}$ and $z_{1}$ heights, respectively,

$$
K_{q}=k u_{*}(z-d) / \phi_{q} .
$$

Where $k$ is the von Kármán constant $(0.4) ; u_{*}$ is the friction velocity $(\mathrm{m} / \mathrm{s})$; and $d$ is the displacement height $(\mathrm{m})$, which equals to 0.65 times the canopy height. $\phi_{q}$ is a dimensionless universal function and the semi-empirical formulas (Dyer, 1974) that describe it under neutral (Eq. 3), unstable (Eq. 4) and stable (Eq. 5) conditions are,

$$
\begin{aligned}
& \phi_{q}(z / L)=1 . \quad(3) ; \quad \phi_{q}(z / L)=\phi_{H}(z / L)=(1-16(z / L))^{-1 / 2} \\
& \phi_{q}(z / L)=\phi_{H}(z / L)=1+5(z / L) . \quad(5) ; \quad L=\frac{-u_{*}{ }^{3}}{k \frac{g}{\theta} \frac{H}{\rho c_{p}}} .
\end{aligned}
$$

Where $L$ is the Obukhov length $(\mathrm{m}), H$ is the sensible heat flux $\left(\mathrm{w} / \mathrm{m}^{2}\right), \theta$ is the potential temperature $(K)$ and $c_{p}$ is the specific heat of air at a constant pressure $(1.004 \mathrm{~J} / \mathrm{kg})$. In addition, some definitions need to be specified here,

$$
\Delta w=\left(w_{2}-w_{1}\right) /\left(h_{2}-h_{1}\right) .
$$

Where $\Delta w$ is the atmospheric water vapor concentration $(\mathrm{mmol} /(\mathrm{mol} \cdot \mathrm{m})), w_{2}$ and $w_{1}$ are 
atmospheric water vapor concentration in the upper and lower layers, respectively $(\mathrm{mmol} / \mathrm{mol})$, and $h_{2}$ and $h_{1}$ are the heights of the upper and lower layers, respectively (m).

Frequency of dew is defined as:

Frequency $=($ Dew days/Observation days $) \times 100 \%$.

Dew amount is the cumulative amount of dew for the three timescales of hourly $(\mathrm{mm} / \mathrm{h})$, daily ( $\mathrm{mm} /$ night) or during the entire observation period $(\mathrm{mm})$.

\section{Results}

\subsection{Seasonal variations of environmental variables}

Figure 1 showed the seasonal variations of the daily mean air temperature, precipitation, daily average atmospheric water vapor concentration and gradient of average atmospheric water vapor concentration in Zhangye and Luancheng. The daily mean air temperature ranged from $9.4^{\circ} \mathrm{C}$ to $27.0^{\circ} \mathrm{C}$ in Zhangye, while it ranged from $9.5^{\circ} \mathrm{C}$ to $36.0^{\circ} \mathrm{C}$ in Luancheng. During the crop growing season, the precipitation occurred at 25 days in Zhangye and 54 days in Luancheng. However, the total amount of precipitation in Luancheng $(498 \mathrm{~mm})$ was almost five times of that in Zhangye $(104 \mathrm{~mm})$. The atmospheric water vapor concentration in Luancheng (from 6.1 to $31.2 \mathrm{mmol} / \mathrm{mol}$ ) was higher than that in Zhangye (from 4.5 to $21.7 \mathrm{mmol} / \mathrm{mol}$ ), but the gradient of atmospheric water vapor concentration was similar in Zhangye (ranging from -0.94 to -0.05 $\mathrm{mmol} /(\mathrm{mol} \cdot \mathrm{m})$ ) and Luancheng (ranging from -1.52 to $0.13 \mathrm{mmol} /(\mathrm{mol} \cdot \mathrm{m})$ ).
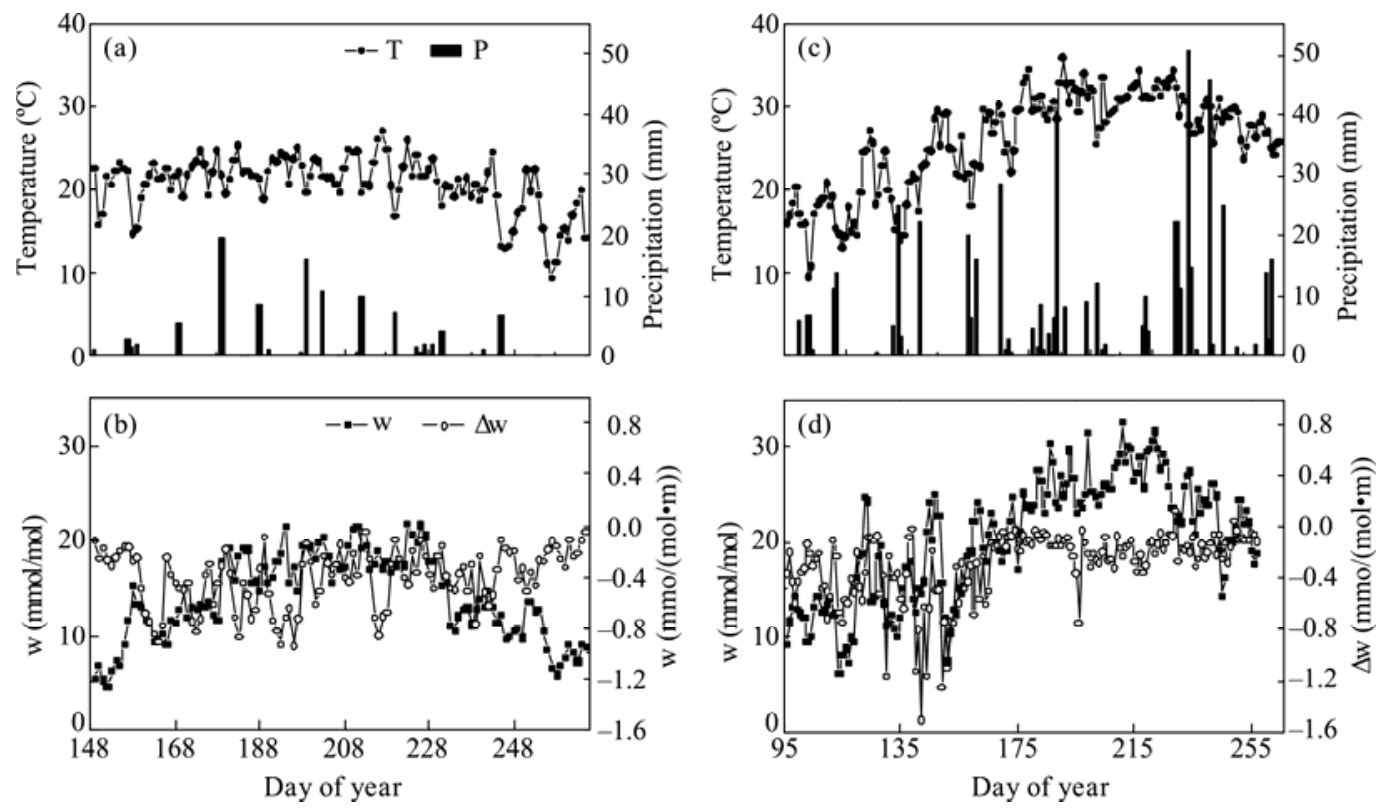

Fig. 1 Seasonal variations of daily average air temperature (T), precipitation (P), average atmospheric water vapor concentration $(\mathrm{w})$ and gradient of average atmospheric water vapor concentration $(\Delta \mathrm{w})$. (a) and (b) from 28 May to 21 September 2012 (day of year (DOY), 149-265) in Zhangye, (c) and (d) from 5 April to 13 September 2008 (DOY 96-257) in Luancheng.

\subsection{Seasonal variations of dew amount and frequency}

Figure 2 showed the seasonal variations of the amount of dew in Zhangye and Luancheng. Over the 117-day observation period (from 28 May to 21 September) in Zhangye, the amount of dewfall first increased and then decreased, and the dew event occurred in 59\% of the observation period. In Luancheng, the amount of dew was relatively more evenly distributed across the 162-day observation period (5 April to 13 September), and dew occurred in $79 \%$ of the observation days. In addition, the frequency of dew events was 2.8 times of the precipitation in Zhangye and 2.4 times of the precipitation in Luancheng. However, the peak of dew happened in 
July in both Zhangye and Luancheng, in which dew events accounted for $81 \%$ (25 days) and 87\% (27 days) of the days in July, respectively. The maximum monthly dew amount also occurred in July, which was 4.4 and $4.8 \mathrm{~mm}$ in Zhangye and Luancheng, respectively.

During the observation days, the total amount of dew reached $9.9 \mathrm{~mm}$ in Zhangye, which accounted for $9.5 \%$ of precipitation. In comparison, the amount of dew was $20.2 \mathrm{~mm}$ in Luancheng, which accounted for $4.1 \%$ of precipitation. In the dew event days, the average dew amount in Zhangye and Luancheng was 0.14 and $0.16 \mathrm{~mm} /$ night, respectively, and the difference was only $0.02 \mathrm{~mm} / \mathrm{night}$. It is noteworthy that the largest daily dew amount $(0.83 \mathrm{~mm} / \mathrm{night})$ in Zhangye occurred from 20:30 on 30 July to 09:00 on 31 July (there was no dew formation for half an hour), and the gradient of average water vapor concentration was $0.48 \mathrm{mmol} /(\mathrm{mol} \cdot \mathrm{m})$, which was suitable for condensation.

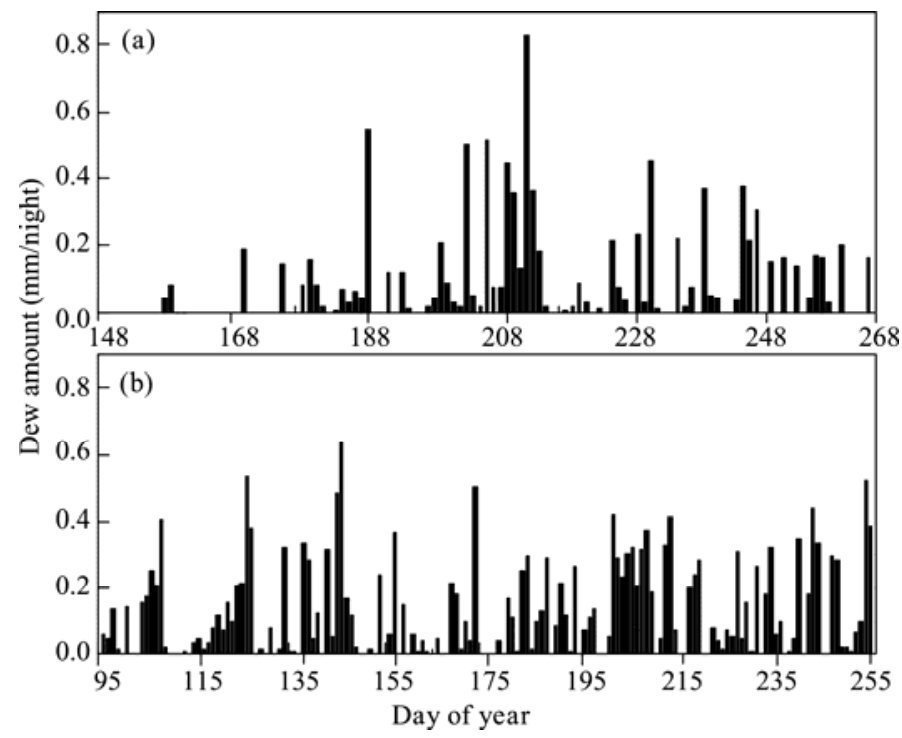

Fig. 2 Seasonal variations of dew amount (a) from 28 May to 21 September 2012 (DOY 149-265) in Zhangye and (b) from 5 April to 13 September 2008 (DOY 96-257) in Luancheng

\subsection{Diurnal variations of dew amount and frequency}

A similar trend of diurnal variations of dew amount and frequency was found in both sites (Fig. 3). The dew amount increased at the beginning of the midnight, and then decreased after 04:00 or 05:00. The peak of dew amount occurred between 04:00 and 05:00 at each night, and the dew amount was 0.022 and $0.020 \mathrm{~mm} / \mathrm{h}$ in Zhangye and Luancheng, respectively. The maximum frequency of dew events occurred between 04:00 and 05:00 in Zhangye, and between 03:00 to 04:00 in Luancheng, which accounted for $46.2 \%$ and $54.9 \%$ of the days during the entire observation period, respectively.

\subsection{Seasonal variations of the duration of dew events}

In Zhangye, dew began to condense on leaf at the earliest 21:00 and terminated by 09:00 the next morning. In comparison, the dew occurred an hour earlier and ended an hour later in the next morning in Luancheng (Fig. 4). The duration of dew events ranged from 0.5 to $12 \mathrm{~h}$ in Zhangye, while 0.5 to $12 \mathrm{~h}$ in Luancheng. The average durations were approximately 5.0 and $5.4 \mathrm{~h}$ in the two sites. Among the observation days, the longest duration of dew events occurred from 20:30 on 30 July to 09:00 on 31 July in Zhangye and from 19:00 on 4 May to 07:00 on 5 May in Luancheng, respectively. 

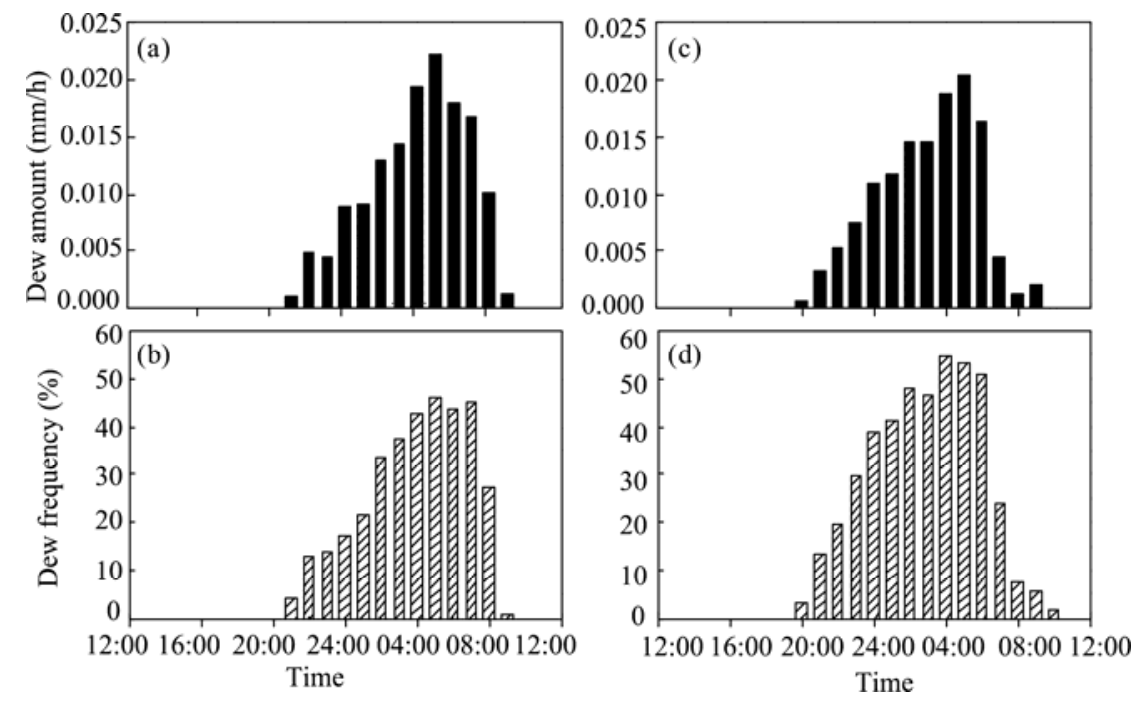

Fig. 3 Diurnal variations of dew amount (a, c) and dew frequency (b, d) from 28 May to 21 September 2012 in Zhangye (a, b), and from 5 April to 13 September 2008 in Luancheng (c, d)

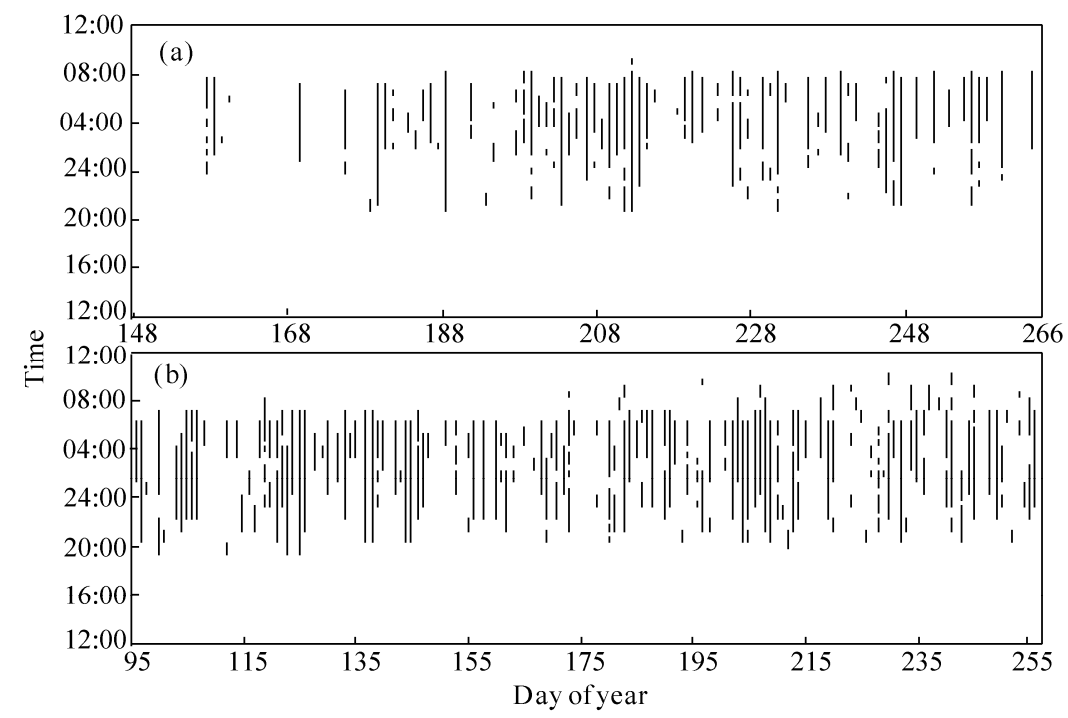

Fig. 4 Seasonal variations of the duration of dew events (a) from 28 May to 21 September 2012 (DOY 149-265) in Zhangye, (b) from 5 April to 13 September 2008 (DOY 96-257) in Luancheng

\subsection{Environmental variations in the presence and absence of dew}

The diurnal variations of relative humidity, temperature, wind speed and the Bowen ratio in presence and absence of dew during observation period (excluding rainfall days) in the two sites were shown in Fig. 5. The micro-climate environment affects the dew formation, but evaporation could create a feedback to the micro-climate environment. As seen in Fig. 5, the impact of evaporation on relative humidity, temperature and wind speed was more significant in Zhangye than in Luancheng. There was a significant difference of Bowen ratio between the presence and absence of dew at night. Besides, Bowen ratio was controlled by sensible and latent heat. The diurnal variations of sensible heat and latent heat were not synchronous. At night, the average value of sensible heat was negative in both presence and absence of dew. The average value of latent heat was positive during absence of dew, and negative during presence of dew, which led to the change of Bowen ratio. 

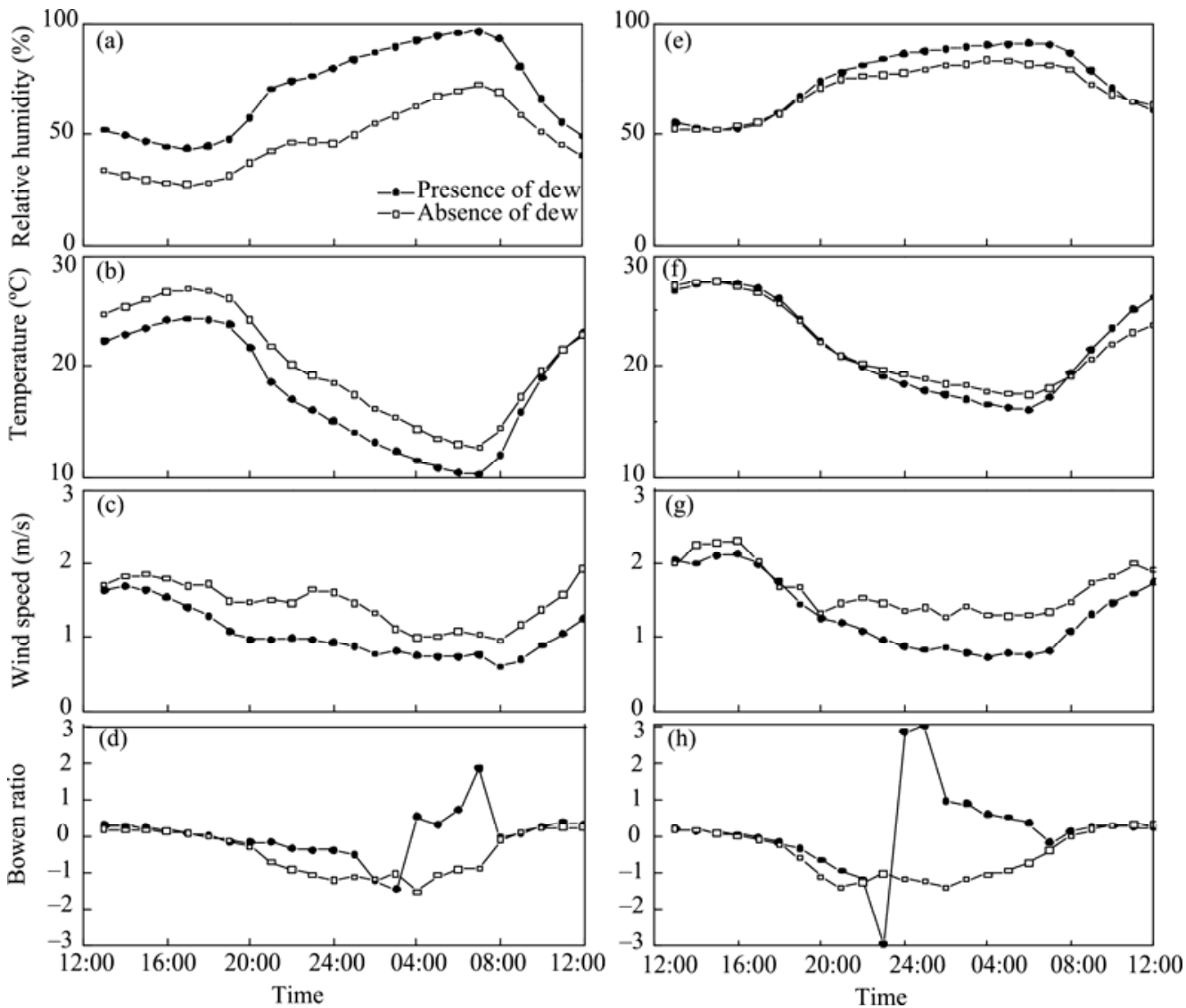

Fig. 5 Diurnal variations of relative humidity $(a, e)$, temperature $(b, f)$, wind speed $(c, g)$ and the Bowen ratio (d, h) in the presence and absence of dew from 28 May to 21 September 2012 (excluding rainfall days) in Zhangye (a, b, c d), and from 5 April to 13 September 2008 (excluding rainfall days) in Luancheng (e, f, g, h)

\subsection{Mechanisms of dew formation}

The results showed that dew amount was associated with the gradient of atmospheric water vapor concentration and dew duration $(P<0.001)$ in both study sites, in which the former mattered more in Zhangye, and the latter mattered more in Luancheng. Therefore, the data were grouped with dew duration (Fig. 6a) in Zhangye and the gradient of atmospheric water vapor concentration (Fig. 6b) in Luancheng. In Zhangye, dew amount was significantly correlated with the gradient of atmospheric water vapor concentration in general, except when dew duration was less than $7 \mathrm{~h}$, especially less than $2.5 \mathrm{~h}$ (Fig. 6a). In comparison, duration of dew significantly influenced dew amount in Luancheng, whereas this relationship was not significant when the gradient of atmospheric water vapor concentration was lower than $0.10 \mathrm{mmol} /(\mathrm{mol} \cdot \mathrm{m})$ (Fig. $6 \mathrm{~b})$.

\section{Discussion}

\subsection{Three sources of dew formation}

Dew is, fundamentally, a result of a phase transition in which water vapor is transformed into liquid water when it contacts a surface (Agam and Berliner, 2006). Three sources of water vapor can be involved in the formation of dew in an ecosystem (Garratt and Segal, 1988; Wen et al., 2012). The water vapor presenting in the lower atmosphere is the dominant source (Wen et al., 2012). Dew from this source is generally called dew deposition, which is a type of fresh water input to plants or land surfaces. The second source of dew is water vapor from soil, which typically maintains a higher temperature than the foliage and the dew point temperature (Richards, 2004; Wen et al., 2012). The last source is transpiration, which originates from the leaves in the 

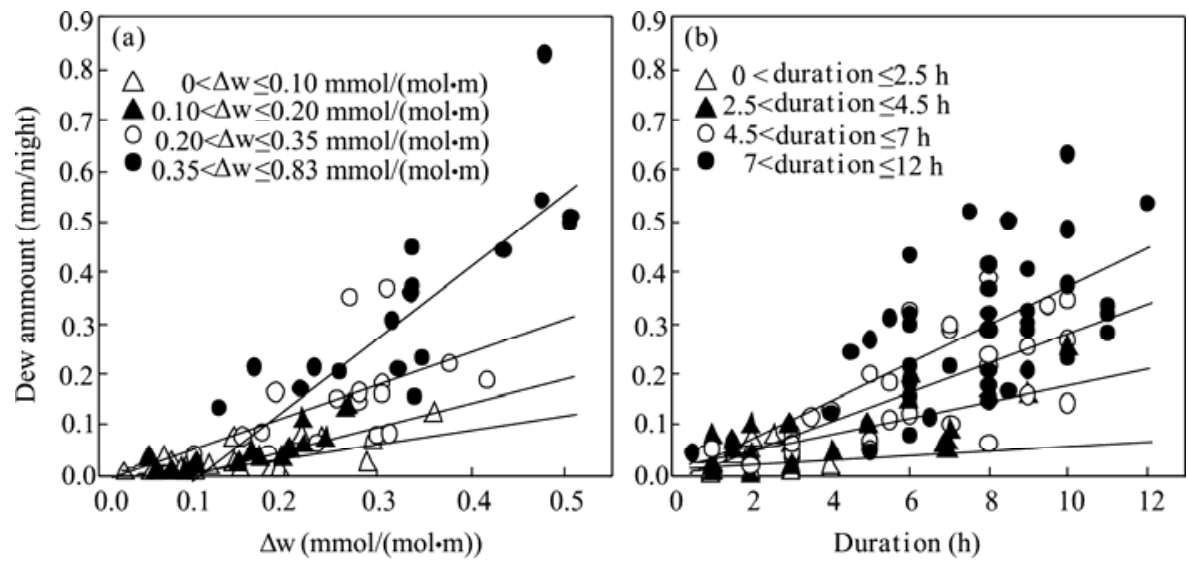

Fig. 6 Relationships between dew amount and gradient of atmospheric water vapor concentration for different dew duration events in Zhangye (a), and between dew amount and duration of dew events for gradients of different atmospheric water vapor concentration in Luancheng (b)

lower canopy (Monteith and Unsworth, 1990). Dew from soil evaporation and plant transpiration is known as distillation (Welp et al., 2008).

The amount of dew observed above the canopy by the flux-profile method is actually a net ecosystem water vapor flux, which is the balance of the movement of water vapor from the atmosphere downward and the flux of evapotranspiration from the lower canopy and soil upward. The ratio between the real dew flux and the net water flux was 1.17 in Luancheng, which was estimated with an isotopic labeling method (Wen et al., 2012). In this study, if the result was underestimated as suggested by Wen et al. (2012), then the corrected amount of dew would be $11.6 \mathrm{~mm}$, which would account for $11.2 \%$ of precipitation in Zhangye. Similarly, the corrected dewfall amount would be $23.6 \mathrm{~mm}$, accounting for $4.7 \%$ of precipitation in Luancheng.

\subsection{Differences in the amount, frequency and duration of dew between arid and sub-humid croplands}

The amount, frequency and duration of dew are influenced by the geographical location, weather, vegetation and irrigation conditions (Kidron, 1999; Kalthoff et al., 2006; Kidron and Temina, 2013). The amount and frequency of dew in Zhangye were lower than those in Luancheng. This is reasonable because the higher wind speed and lower relative humidity, common to arid areas, inhibit the formation of dew. In contrast, the higher relative humidity in humid areas is more favorable to the formation of dew (Beysens et al., 2005).

The flux-profile method has been used in micro-climate for many years, but it is still a new try to quantify dew events. We compared the results with the dew in some similar climate zones measured with traditional ways, and found a good consistency. For example, the dew amount in Zhangye was close to the annual amount of dew in the Elqui valley (also an arid area), which ranged from 5 to $10 \mathrm{~mm}$ (Kalthoff et al., 2006). However, the dew frequency in Zhangye was lower than that in a desert riparian forest ecosystem on the eastern edge of the Taklimakan Desert in China (73\%), and the dew amount was higher than the desert area $(0.12 \mathrm{~mm} / \mathrm{night})$ (Hao et al., 2012). This is because the temperature gradient was higher for dew formation in Taklimakan Desert, but the atmospheric water vapor concentration was lower. The average of daily dew amount in Luancheng was close to that in the soybean and corn farmlands $(0.19-0.30 \mathrm{~mm} / \mathrm{night})$ (Yan et al., 2010), less than that in rice paddy field $(0.49-0.67 \mathrm{~mm} / \mathrm{night}$ ) (Xu et al., 2013) of Sanjiang Plain. The atmospheric water vapor concentration in rice paddy field was higher. The amount of dew in the dry farmland and the rice paddy field of the Sanjiang Plain accounted for $4 \%$ and $10 \%$ of precipitation, respectively, during the same period.

The duration of dew events did not differ significantly between Zhangye and Luancheng. But in some previous studies, the difference of dew durations in different areas could be significant. For example, the duration of dew at a desert oasis ecotone in northwestern China was $2 \mathrm{~h}$ (Zhuang 
and Zhao, 2014), and that in Utah, a semi-arid area in the USA, could be as long as $14 \mathrm{~h}$ during the irrigation period of the alfalfa growing season (Malek et al., 1999). In Balsa Blanca, a semi-arid area, the duration of dew could last as long as $9.6 \mathrm{~h}$ in a grass ecosystem (Uclés et al., 2014). The weather condition and artificial measurement could be the causes of these differences. For example, irrigation is beneficial for dew.

\section{Conclusions}

In conclusion, although the precipitation between Zhangye (an arid area) and Luancheng (a sub-humid area) was significantly different, the occurrence frequency and the amount per night in the two sites were similar. Therefore, dew in arid area accounted for more of the local water source and played a more important role in the local agroecological system. The gradient of atmospheric water vapor concentration and the duration of dew were the two primary factors determining the daily dew amount in both sites, but the former was more important in the arid area.

\section{Acknowledgements}

This research was supported by the National Natural Science Foundation of China (91125002) and the Strategic Priority Research Program of Chinese Academy of Sciences (XDA05050601).

\section{References}

Agam N, Berliner P R. 2006. Dew formation and water vapor adsorption in semi-arid environments—a review. Journal of Arid Environments, 65(4): 572-590.

Barradas V L, Glez-Medellín M G. 1999. Dew and its effect on two heliophile understorey species of a tropical dry deciduous forest in Mexico. International Journal of Biometeorology, 43(1): 1-7.

Beysens D, Muselli M, Nikolayev V, et al. 2005. Measurement and modelling of dew in island, coastal and alpine areas. Atmospheric Research, 73(1-2): 1-22.

Beysens D, Clus O, Mileta M, et al. 2007. Collecting dew as a water source on small islands: the dew equipment for water project in Biševo (Croatia). Energy, 32(6): 1032-1037.

Businger J, Wyngaard J, Izumi Y, et al. 1971. Flux-profile relationships in the atmospheric surface layer. Journal of the Atmospheric Sciences, 28(2): 181-189.

Cosh M H, Kabela E D, Hornbuckle B, et al. 2009. Observations of dew amount using in situ and satellite measurements in an agricultural landscape. Agricultural and Forest Meteorology, 149(6-7): 1082-1086.

Dai A G. 2006. Recent climatology, variability, and trends in global surface humidity. Journal of Climate, 19(15): 3589-3606.

De Roode S R, Bosveld F C, Kroon P S. 2010. Dew formation, eddy-correlation latent heat fluxes, and the surface energy imbalance at Cabauw during stable conditions. Boundary-Layer Meteorology, 135(3): 369-383.

Dietz J, Leuschner C, Hölscher D, et al. 2007. Vertical patterns and duration of surface wetness in an old-growth tropical montane forest, Indonesia. Flora-Morphology, Distribution, Functional Ecology of Plants, 202(2): 111-117.

Dyer A J. 1974. A review of flux-profile relationships. Boundary-layer Meteorology, 7(3): 363-372.

Garratt J R, Segal M. 1988. On the contribution of atmospheric moisture to dew formation. Boundary-layer Meteorology, 45(3): 209-236.

Hao X M, Li C, Guo B, et al. 2012. Dew formation and its long-term trend in a desert riparian forest ecosystem on the eastern edge of the Taklimakan Desert in China. Journal of Hydrology, 472-473: 90-98.

Huang L J, Wen X F. 2014. Temporal variations of atmospheric water vapor $\delta \mathrm{D}$ and $\delta^{18} \mathrm{O}$ above an arid articial oasis cropland in the Heihe River Basin. Journal of Geophysical Research, 119(19): 11456-11476.

Kabela E D, Hornbuckle B K, Cosh M H, et al. 2009. Dew frequency, duration, amount, and distribution in corn and soybean during SMEX05. Agricultural and Forest Meteorology, 149(1): 11-24.

Kalthoff N, Fiebig-Wittmaack M, Meißner C, et al. 2006. The energy balance, evapo-transpiration and nocturnal dew deposition of an arid valley in the Andes. Journal of Arid Environments, 65(3): 420-443.

Kidron G J. 1999. Altitude dependent dew and fog in the Negev Desert, Israel. Agricultural and Forest Meteorology, 96(1-3): $1-8$.

Kidron G J, Temina M. 2013. The effect of dew and fog on lithic lichens along an altitudinal gradient in the Negev Desert. Geomicrobiology Journal, 30(4): 281-290.

Kim K, Lee X. 2011. Transition of stable isotope ratios of leaf water under simulated dew formation. Plant, Cell \& Environment, 
34(10): 1790-1801.

Li X, Cheng G D, Liu S M, et al. 2013. Heihe watershed allied telemetry experimental research (HiWATER): scientific objectives and experimental design. Bulletin of the American Meteorological Society, 94(8): 1145-1160.

Madeira A C, Gillespie T J, Duke C L. 2001. Effect of wetness on turfgrass canopy reflectance. Agricultural and Forest Meteorology, 107(2): 117-130.

Malek E, McCurdy G, Giles B. 1999. Dew contribution to the annual water balances in semi-arid desert valleys. Journal of Arid Environments, 42(2): 71-80.

Monteith J, Unsworth M. 1990. Principles of Environmental Physics (2 ${ }^{\text {nd }}$ ed.). London: Edward Arnold, 291.

Moro M J, Were A, Villagarcía L, et al. 2007. Dew measurement by eddy covariance and wetness sensor in a semiarid ecosystem of SE Spain. Journal of Hydrology, 335(3-4): 295-302.

Richards K. 2004. Observation and simulation of dew in rural and urban environments. Progress in Physical Geography, 28(1): 76-94.

Sharan G, Beysens D, Milimouk-Melnytchouk I. 2007. A study of dew water yields on galvanized iron roofs in Kothara (North-West India). Journal of Arid Environments, 69(2): 259-269.

Uclés O, Villagarcía L, Moro M J, et al. 2014. Role of dewfall in the water balance of a semiarid coastal steppe ecosystem. Hydrological Processes, 28(4): 2271-2280.

Welp L R, Lee X, Kim K, et al. 2008. $\delta^{18} \mathrm{O}$ of water vapour, evapotranspiration and the sites of leaf water evaporation in a soybean canopy. Plant, Cell \& Environment, 31(9): 1214-1228.

Wen X F, Lee X, Sun X M, et al. 2012. Dew water isotopic ratios and their relationships to ecosystem water pools and fluxes in a cropland and a grassland in China. Oecologia, 168(2): 549-561.

Willett K M, Gillett N P, Jones P D, et al. 2007. Attribution of observed surface humidity changes to human influence. Nature, 449(7163): 710-712.

Wilson T B, Bland W L, Norman J M. 1999. Measurement and simulation of dew accumulation and drying in a potato canopy. Agricultural and Forest Meteorology, 93(2): 111-119.

Xiao W, Lee X, Wen X F, et al. 2012. Modeling biophysical controls on canopy foliage water ${ }^{18} \mathrm{O}$ enrichment in wheat and corn. Global Change Biology, 18(5): 1769-1780.

Xu Y Y, Yan B X, Zhu H. 2013. Leaf dew contributes nutrients to paddies and improves rice growth. Acta Agriculturae Scandinavica, Section B-Soil \& Plant Science, 63(2): 97-106.

Yan B X, Deng W. 2004. Study on the dew resource in Sanjiang Plain. Journal of Natural Resources, 19(6): 732-737. (in Chinese)

Yan B X, Xu Y Y, Wang L X. 2010. Dew condensation rules in farmland ecosystem in Sanjiang Plain. Acta Ecologica Sinica, 30(20): 5577-5584. (in Chinese)

Yang B, Wen X F, Sun X M. 2015. Irrigation depth far exceeds water uptake depth in an oasis cropland in the middle reaches of Heihe River Basin. Scientific Reports, 5: 15206.

Zangvil A. 1996. Six years of dew observations in the Negev Desert, Israel. Journal of Arid Environments, 32(4): 361-371.

Zhang H, Wen X F. 2015. Flux footprint climatology estimated by three analytical models over a subtropical coniferous plantation in Southeastern China. Journal of Meteorological Research, 29(4): 654-666.

Zhuang Y L, Ratcliffe S. 2012. Relationship between dew presence and Bassia dasyphylla plant growth. Journal of Arid Land, 4(1): 11-18.

Zhuang Y L, Zhao W Z. 2014. Dew variability in three habitats of a sand dune transect in a desert oasis ecotone, northwestern China. Hydrological Processes, 28(3): 1399-1408. 